\title{
The longicorn beetle tribe Cerambycini Latreille, 1802 (Coleoptera: Cerambycidae: Cerambycinae) in the fauna of Asia. 13. A new species of the genus Dymasius J. Thomson, 1864 from Borneo
}

\section{ЖКуки-Аровосеки трибы Cerambycini Latreille, 1802 (Coleoptera: Cerambycidae: Cerambycinae) фауны Азии. 13. Новый вид рода Dymasius J. Thomson, 1864 с Борнео}

\author{
Alexandr I. Miroshnikov ${ }^{1,2}$, Daniel J. Heffern ${ }^{3}$ \\ А.И. Мирошников ${ }^{1,2}, A_{.}, \Delta ж$. Хефферн ${ }^{3}$
}

\footnotetext{
'Russian Entomological Society, Krasnodar, Russia. E-mail: miroshnikov-ai@yandex.ru

${ }^{2}$ Sochi National Park, Moskovskaya str. 21, Sochi, Krasnodar region, 354002 Russia.

${ }^{3}$ Florida State Collection of Arthropods, Museum of Entomology, 10531 Goldfield Lane, Houston, TX 77064 USA. E-mail: titanusgiganteus@hotmail.com

Русское энтомологическое общество, Краснодар, Россия.

${ }^{2}$ Сочинский национальный парк, ул. Московская 21, Сочи, Краснодарский край, 354002 Россия.
}

KEY WORDS: Coleoptera, Cerambycidae, Cerambycini, Dymasius, new species, Malaysia, Sabah.

КЛЮЧЕВЫЕ СЛОВА: Coleoptera, Cerambycidae, Cerambycini, Dymasius, новый вид, Малайзия, Сабах.

ABSTRACT. Dymasius borneoensis Miroshnikov et Heffern, sp.n., is described from Borneo. By the habitus, it resembles $D$. hefferni Holzschuh, 2005 also from Borneo, but is distinguished through the clearly less coarse folds on the pronotal disc, the significantly smaller, relatively homogeneous puncturation of the elytra, the more slender body, the clearly longitudinal antennomere 2, and the shape of the elytral apex.

РЕЗЮМЕ. ОПисан новый вид Dymasius borneoensis Miroshnikov et Heffern, sp.n. с Борнео. Габитуально он напоминает D. hefferni Holzschuh, 2005, распространённого также на Борнео, но отличается явно менее грубыми складками на диске переднеспинки, значительно более мелкой, сравнительно однородной пунктировкой надкрылий, более стройным телом, явно продольным 2-м члеником усиков, формой вершины надкрылий.

\section{Introduction}

The genus Dymasius J. Thomson, 1864 currently has at least 19 species in the fauna of Borneo [Heffern, 2013; Holzschuh, 2015, 2016, 2017; Miroshnikov, 2018; Tavakilian, Chevillotte, 2019], which is nearly one-third of the total composition of the genus. In so doing, the vast majority of species are still known only from this area.
This paper describes a new species of this genus based on a specimen collected in Sabah, East Malaysia.

The material examined is kept in the following institutional and private collections:

BMNH - Natural History Museum (London, United Kingdom);

NHMD - Natural History Museum of Denmark, University of Copenhagen (Copenhagen, Denmark);

cAM - collection of Alexandr Miroshnikov (Krasnodar, Russia);

$\mathrm{cCH}$ - collection of Carolus Holzschuh (Villach, Austria);

cDH - collection of Daniel Heffern (Houston, Texas, USA).

Dymasius borneoensis Miroshnikov et Heffern, sp.n. Figs 1, 4, 5.

MATERIAL. Holotype + (cDH) (Fig. 1), E Malaysia, Sabah, Ranau, 1000 m, 5.05.2012 (local collector).

COMPARATIVE MATERIAL. Dymasius hefferni Holzschuh, 2005: holotype $\sigma^{7}(\mathrm{cCH})$ (photograph); $1 \sigma^{7}$ (NHMD), E Malaysia, Sabah, Trus Madi Mt., 28.III.2000, local collector, "Dymasius hefferni Holz. Ole Mehl det. 2005"; 10", 1 ㅇ (NHMD), same labels, but III.2003; $10^{7}$ (cAM), same labels; 19 (NHMD), same labels, but III.2005; 10', 4ㅇ, (Fig. 2) (NHMD), same locality, but IV.2014, local collector, "Dymasius hefferni Holz. O. Mehl det. 2014"; 1 ㅇ (cAM), same labels; 1 우 (NHMD), E Malaysia, Sabah, Crocker Range, III.2005, local collector, "Dymasius hefferni Holz. Ole Mehl det. 2005"; $10^{7}$ (cAM), E Malaysia, Sabah, Trus Madi Mt., 1250 m, $05^{\circ} 26^{\prime} 35^{\prime \prime} \mathrm{N} / 116^{\circ} 27^{\prime} 5^{\prime \prime}$ E, 22-26.V.2014, leg. A. Klimenko.

How to cite this article: Miroshnikov A.I., Heffern D.J. 2020. The longicorn beetle tribe Cerambycini Latreille, 1802 (Coleoptera: Cerambycidae: Cerambycinae) in the fauna of Asia. 13. A new species of the genus Dymasius J. Thomson, 1864 from Borneo // Russian Entomol. J. Vol.29. No.2. P.184-186. doi: 10.15298/rusentj.29.2.10 

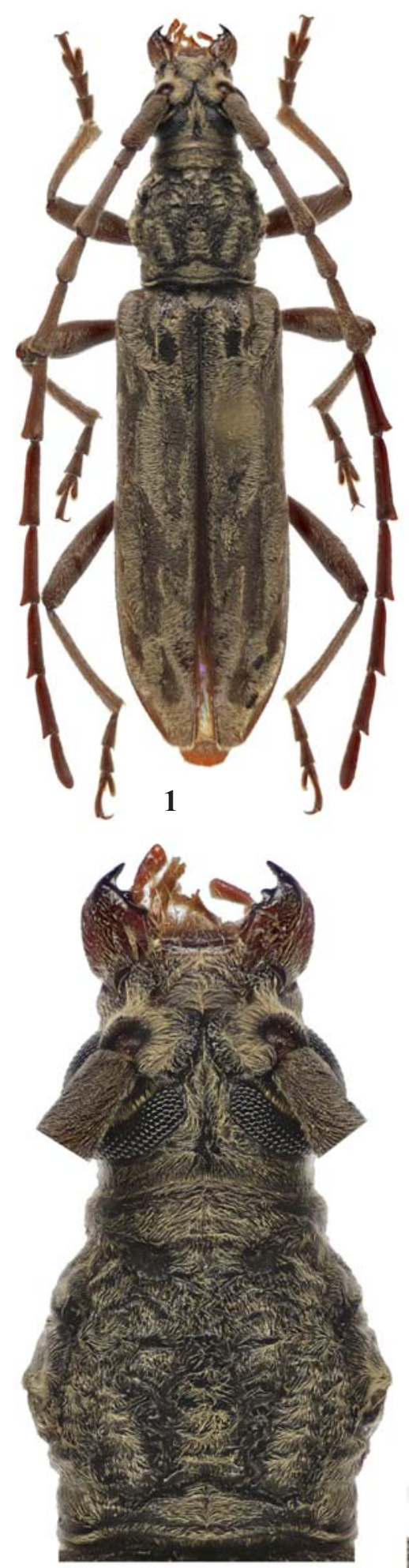

4
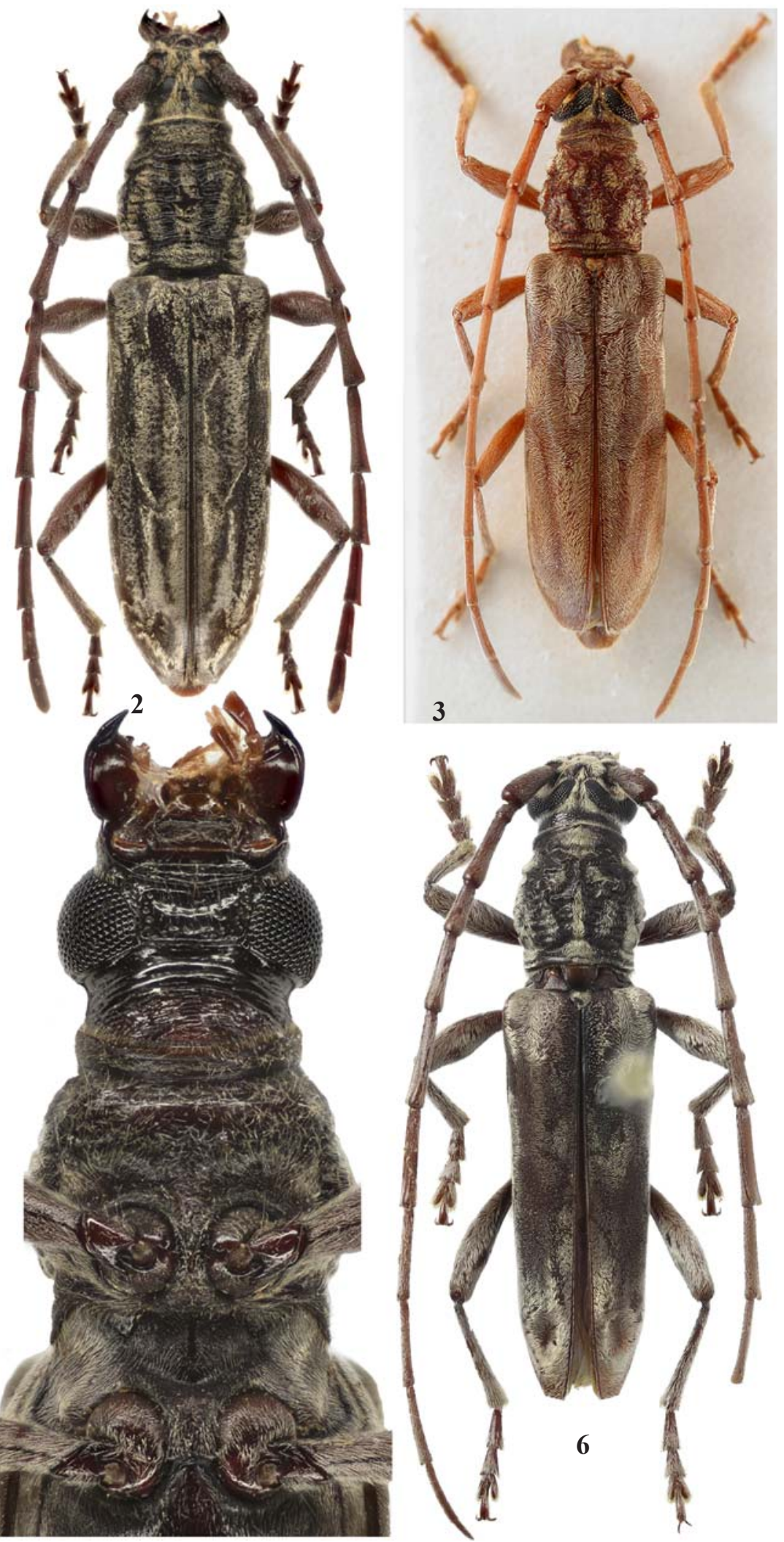

Figs 1-6. Dymasius spp: 1, 4,5-D. borneoensis sp.n.; $2-D$. hefferni; $3-D$. nimbatus (photograph by Luboš Dembický); $6-D$. vitreus; $1-3$, 6 - habitus, dorsal view; 4 - head and pronotum, dorsal view; 5 - head, pro- and mesosternum, ventral view; 1, 3-6 - holotypes; $1-5$ - $9+, 6$ - $\sigma^{T}$. Рис. 1-6. Dymasius spp.: 1, 4, 5-D. borneoensis sp.n.; 2 - D. hefferni; 3 - D. nimbatus (фотография Л.Дембицкого); 6 - D. vitreus; 1-3, 6 - общий вид, сверху; 4 - голова и переднеспинка, сверху ; 5 - голова, про- и мезостернум, снизу; 1, 3-6 - голотипы; 1-5 - о, 6 - О’. 
Dymasius nimbatus Holzschuh, 1991: holotype, + (cCH) (photograph; Fig. 3).

Dymasius vitreus Pascoe, 1885: holotype, O' (BMNH) (Fig. 6), "N. Borneo", "Dymasius vitreus Pasc. Type", "Type", "Pascoe Coll. 9360.", "Dymasius vitreus Pasc. N. Borneo"; $10^{7}$ (NHMD), E Malaysia, Sabah, Crocker Range, III.2005, local collector, "Dymasius vitreus Pasc. Holzschuh det. 2006"; 19 (NHMD), same locality, but taken on IV.2005, local collector, "Dymasius vitreus Pasc. Ole Mehl det. 2007".

DIAGNOSIS. By the habitus, this new species resembles D. hefferni Holzschuh, 2005, but is distinguished through the clearly less coarse folds on the pronotal disc, the significantly smaller, relatively homogeneous puncturation of the elytra, the more slender body, the clearly longitudinal antennomere 2 , the shape of the elytral apex, the length ratio of antennomeres 4-6, and some other traits. Dymasius borneoensis sp.n. can also be compared to D. nimbatus Holzschuh, 1991 (see Remarks below), but differs distinctly by the larger body size, the significantly darker coloration, the wider pronotum, the longitudinal antennomere 2, the somewhat peculiar, recumbent, light setation of the elytra. In addition, the new species is distinguished from the somewhat similar congener, $D$. vitreus Pascoe, 1885 , by the shape of the pronotum and elytra, including the apex of the latter, the more strongly elongate antennomere 2 , the somewhat peculiar, recumbent, light setation of the dorsum.

DESCRIPTION. Female. Body length $18.5 \mathrm{~mm}$, humeral width $4.2 \mathrm{~mm}$. Eyes, part of mandibles, most of head dorsally and pronotal disc black; elytra mostly dark brown; coloration of remaining parts combines brown and reddish brown tones.

Head with a distinct, relatively short, median groove between upper lobes of eyes; antennal tubercles well-expressed; eyes moderately convex; submentum with coarse and rough punctures and in addition with transverse folds; genae moderately long; antennae slightly longer than body; length ratio of antennomeres $1-11,34: 10: 39: 23: 38: 43$ $: 43: 40: 39: 33: 33$; antennomere 1 without cicatrix (apical carina), with clear dense punctures; antennomere 2 very distinctly longitudinal.

Pronotum barely transverse, 1.01 times as wide as long; base 1.25 times as wide as apex; disc weakly convex, with moderately coarse and rough, heterogeneous, partly sinuous, predominantly transverse folds.

Scutellum triangular, strongly narrowed towards apex.

Elytra nearly parallel-sided, 2.8 times as long as humeral width; mainly with a small, clear, very dense, partly heterogeneous puncturation; apical external angle obtuse-angled, but well-expressed, sutural angle feebly dentate.

Prosternum with distinct transverse groove in front of middle, with irregular, partly transverse folds; prosternal process without apical tubercle; mesosternal process between coxae 1.5 times as wide as prosternal process, without tubercle dorsally; metasternum and sternites with a small dense puncturation; metasternum with a median groove being more distinct in apical part; both last (visible) sternite and tergite widely rounded at apex.
Legs moderately long; femora and tibiae with a distinct longitudinal carina on sides; metatarsomere 1 clearly shorter than metatarsomeres 2 and 3 combined.

Recumbent setation of dorsum mainly silvery greyish, of venter greyish, forming on elytra an iridescent pattern and on pronotum a peculiar pattern, as in Figs 1, 4; more or less long, erect, light setae mostly developed on head, pronotum, apex of abdomen and partly on venter.

ETYMOLOGY. The epithet of this new species is formed on the basis of the name of the locality it supports.

DISTRIBUTION. East Malaysia.

REMARKS. A specimen of Dymasius from East Kalimantan, indicated as D. nimbatus [Makihara, 1999], does not actually belong to this species and requires a detailed study to determine the correct species attribution. Thus, $D$. nimbatus remains known only from northern Thailand.

Acknowledgements. We are very grateful to Maxwell V.L. Barclay and Michael F. Geiser (BMNH), Alexey Yu. Solodovnikov (NHMD) for the opportunity to study the museum material, to Luboš Dembický (Brno, Czech Republic) who generously shared pictures of the holotypes of some Dymasius species, to Hiroshi Makihara (Isumi, Chiba, Japan) for the helpful provision of literature data. We would also like to express our sincere thanks to Tatiana P. Miroshnikova (Krasnodar, Russia) for having rendered great help in the preparation of pictures.

\section{References}

Heffern D.J. 2013. A Catalog and Bibliography of Longhorned Beetles from Borneo (Coleoptera: Cerambycidae, Disteniidae and Vesperidae). Electronic Version, 2013.1. 107 pp. Available at: https://www.zin.ru/animalia/coleoptera/pdf/heffern 2013 borneo_catalog.pdf (accessed 30 April 2020).

Holzschuh C. 2015. Zehn neue Bockkäfer aus Südostasien und Bemerkungen zur Gattung Microdymasius Pic, 1946 (Coleoptera, Cerambycidae) // Les Cahiers Magellanes. No.19. S.41-53.

Holzschuh C. 2016. Beschreibung von sieben neuen Bockkäfern aus Asien (Coleoptera, Cerambycidae) // Les Cahiers Magellanes. No.24. S.105-113.

Holzschuh C. 2017. Beschreibung neuer Gattung und Arten von Bockkäfern aus Asien (Coleoptera, Cerambycidae) // Les Cahiers Magellanes. No.26. S.1-18.

Makihara H. 1999. Atlas of longicorn beetles, in Bukit Soeharto Education Forest, Mulawarman University, East Kalimantan, Indonesia. Pusrehut special publication No.7. 140 pp.

Miroshnikov A.I. 2018. The longicorn beetle tribe Cerambycini Latreille, 1802 (Coleoptera: Cerambycidae: Cerambycinae) in the fauna of Asia. 4. New or little-known taxa, mainly from Indochina and Borneo, with reviews or annotated checklists of species of some genera // Caucasian Entomological Bulletin. Vol.14. No.2. P.197-246. Pls1-6. DOI: 10.23885/181433262018142-197246.

Tavakilian G.L., Chevillotte H. 2019. Titan: base de données Titan sur les Cerambycidés ou Longicornes. Available at: http:// titan.gbif.fr/ (accessed 30 April 2020). 